\title{
Developing Epistemic Aims and Supports for Engaging Students in Scientific Practices
}

\author{
Gregory J. Kelly ${ }^{1}$
}

Published online: 11 May 2018

(C) Springer Science+Business Media B.V., part of Springer Nature 2018

Educators have called for shifts in our perspectives on science education to increasingly view science as a set of sociocultural practices, with an emphasis on engaging students in the knowledge and practices of disciplinary communities (Duschl 2008; Kelly and Chen 1999; NRC 2011). The epistemic practices of disciplinary communities can shed light on ways that knowledge is constructed and can open multiple pathways for making sense of phenomena. Nevertheless, these practices also can be unfamiliar and potentially alienating to students. Thus, engaging students in practices similar to those of science and engineering professional communities requires attention to the normative goals of education. Educators not only need to consider the value of science and engineering practices, but also recognize that students need support and opportunities that facilitate engagement in disciplinary practices. Research from the history, philosophy, and sociology (HPS) of science can shed light on the normative goals and actual practices of science (Longino 2002; Lynch 1993).

Learning progressions provide one way to consider how to develop and build student learning, application, and evaluation of science and engineering practices in educational settings. The reform-oriented book, Taking Science to School (NRC 2007), defines learning progressions as "descriptions of the successively more sophisticated ways of thinking about a topic that can follow one another as children learn about and investigate a topic over a broad span of time (e.g., six to eight years)" (p. 219). Whereas learning progressions often have been framed as linear or sequential in the context of conceptual learning, research suggests that students' engagement in science practices is context dependent and non-linear, creating tensions between traditional conceptualizations of learning progressions and developing supports for students as they engage in science practices across the curriculum.

Science \& Education will host a special issue (guest edited by Ashlyn Pierson and Douglas Clark; see the call for papers in the back matter of this volume) entitled Scientific Practices, Epistemic Aims, and Learning Progressions, to explore how science practices and epistemic aims might be systematically supported over time within the curriculum. The special issue will

Gregory J. Kelly

gkelly@psu.edu

1 College of Education, Penn State College, 241 Chambers Building, University Park, PA 16802, USA 
examine (a) tensions in educational experiences aimed at developing three-dimensional learning incorporating disciplinary core ideas, science and engineering practices, and crosscutting concepts; (b) the range and types of disciplinary practices; and (c) new perspectives on the design of learning progressions for science and engineering practices. Research related to the development of learning progressions needs to examine ways that epistemic aims are tied to the learning and justification of disciplinary knowledge. This requires consideration of multiple disciplinary perspectives, including human development, learning theory, epistemology, and teacher education, among others.

Science \& Education focuses on how research from history, philosophy, and sociology of science (HPS) can inform and enrich approaches to improve science teaching. The development of epistemic aims of educational experiences can be informed by historical, philosophical, and sociological studies of science (Kelly et al. 2012) in order to identify worthy educational aims centered on the value and dangers of science and technology in society. Contributions to the special issue should draw from literature in the history, philosophy, and sociology of science and have clear implications for science teaching and learning.

The upcoming special issue seeks to address ways that educators shape and respond to students' epistemic aims as they appropriate and enact scientific practices within the disciplinary communities that emerge within science classrooms. This implies the need for a consideration of the normative goals of rationality, reasonableness, and skepticism (Robinson 2009), as well as the descriptive procedures of knowledge construction as it is made in situ. In an era of increased mistrust and skepticism of science and expertise, and in light of the continued specialization of knowledge that renders comprehension among non-scientists more difficult, there is a clear need for consideration of new models for learning experiences, trajectories, and ecologies, and the ways students' epistemic aims are shaped by curricula.

\section{Compliance with Ethical Standards}

Conflict of Interest The author declares no conflict of interest.

\section{References}

Duschl, R. A. (2008). Science education in three-part harmony: balancing conceptual, epistemic, and social learning goals. Review of Research in Education, 32, 268-291.

Kelly, G. J., \& Chen, C. (1999). The sound of music: constructing science as sociocultural practices through oral and written discourse. Journal of Research in Science Teaching, 36, 883-915.

Kelly, G. J., McDonald, S., \& Wickman, P. O. (2012). Science learning and epistemology. In K. Tobin, B. Fraser, \& C. McRobbie (Eds.), Second international handbook of science education (pp. 281-291). Dordrecht: Springer.

Longino, H. E. (2002). The fate of knowledge. Princeton: Princeton University Press.

Lynch, M. (1993). Scientific practice as ordinary action: ethnomethodology and the social studies of science. Cambridge: Cambridge University Press.

National Research Council. (2007). In R. A. Duschl, H. A. Schweingruber, \& A. W. Shouse (Eds.), Taking science to school: learning and teaching science in grades $K-8$. Washington: The National Academies Press.

National Research Council. (2011). A framework for k-12 science education: practices, crosscutting concepts, and core ideas. Committee on a Conceptual Framework for New k-12 Science Education Standards. Washington, DC: The National Academies Press.

Robinson, E. (2009). The epistemic aims of education. In H. Seegel (Ed.), The Oxford handbook of philosophy of education. Oxford: Oxford University Press. 